\title{
PENGARUH MOTIVASI BELAJAR, KINERJA INTENSITAS PEMBIMBINGAN PRAKERIN TERHADAP KESIAPAN KERJA SISWA SMK PARIWISATA DIY
}

\author{
Zuniarti \\ SMKN 1 Sewon \\ zuniarti.aryanti@gmail.com \\ Budi Tri Siswanto \\ Universitas Negeri Yogyakarta \\ buditrisiswanto@gmail.com
}

\begin{abstract}
Abstrak
Penelitian ini bertujuan mengetahui: (1) bagaimanakah tingkat motivasi belajar, kinerja Prakerin, intensitas pembimbingan guru Prakerin dan kesiapan kerja; (2) pengaruh masing-masing variabel motivasi belajar, kinerja Prakerin, intensitas pembimbingan guru Prakerin terhadap kesiapan kerja; dan (3) pengaruh secara bersama-sama variabel motivasi belajar, kinerja Prakerin, intensitas pembimbingan guru Prakerin terhadap kesiapan kerja siswa SMK Pariwisata Kompetensi Keahlian Jasa Boga di DIY. Penelitian ini merupakan penelitian survey dengan pendekatan ex post facto. Teknik analisis data yang digunakan adalah analisis deskriptif, analisis regresi linier sederhana dan analisis regresi ganda dengan bantuan software SPSS 16. Kesimpulan penelitian menunjukkan: (1) Variabel motivasi belajar, intensitas pembimbingan guru Prakerin dan kesiapan kerja diperoleh kategori sedang serta kinerja Prakerin dalam kategori rendah; (2) terdapat pengaruh positif dan signifikan variabel motivasi belajar terhadap kesiapan kerja; (3) terdapat pengaruh positif dan signifikan Variabel kinerja Prakerin terhadap kesiapan kerja; (4) terdapat pengaruh positif dan signifikan variabel intensitas pembimbingan guru Prakerin terhadap kesiapan kerja; dan (5) terdapat pengaruh positif dan signifikan secara bersama-sama ketiga variabel independen terhadap variabel dependen.
\end{abstract}

Kata kunci: pengaruh motivasi belajar, kinerja prakerin, intensitas pembimbingan guru prakerin, kesiapan kerja

\section{THE INFLUENCE OF LEARNING MOTIVATION, PERFORMANCE, INTENSITY OF PRAKERIN MENTORING ON WORK READINESS OF STUDENTS IN TOURISM VOCATIONAL HIGH SCHOOL YOGYAKARTA SPECIAL REGION}

\begin{abstract}
This study aimed to find out: (1) how is the learning motivation, Prakerin performance, intensity of Prakerin teacher mentoring and job readiness; (2) the effect of each variable motivation, Prakerin performance, intensity of Prakerin teacher mentoring on work readiness; and (3) the influence of variables motivation, Prakerin performance, intensity of Prakerin teacher mentoring in aggregate on work readiness of students in Vocational High School Majoring in Catering Services in Yogyakarta Special Region. This was a survey research with ex post facto approach study. The data were analyzed using the descriptive analysis technique, simple liner regression analysis and multiple regression analysis with the help of software SPSS 16. Research conclusion shows: (1) variable learning motivation, intensity of Prakerin teacher mentoring and job readiness are in the fair category obtained and Prakerin the performance in the low category; (2) there is a positive and significant influence of learning motivation on work readiness; (3) there is a positive and significant influence of Prakerin performance on job readiness; (4) there is a positive and significant influence of intensity Prakerin teacher mentoring on job readiness; and (5) there is a positive and significant influence of the three independent variables in aggregate on the dependent variable.
\end{abstract}

Keywords: influence of learning motivation, performance in prakerin, intensity of mentoring, work readiness 


\section{PENDAHULUAN}

Pada era global yang ditandai dengan persaingan mutu, menuntut semua pihak dalam berbagai bidang tidak terkecuali bidang pendidikan untuk senantiasa meningkatkan kompetensinya. Dengan demikian diharapkan dunia pendidikan mampu menyiapkan sumber daya manusia (SDM) yang siap kerja. Hal ini disebabkan karena kualitas sumber daya manusia memiliki peranan penting dan strategis dalam memenuhi tuntutan pembangunan bangsa dewasa ini dalam berbagai bidang, serta berhubungan erat dengan kemajuan dan kemakmuran suatu bangsa. Salah satu upaya untuk meningkatkan SDM yang berkualitas, adalah bidang pendidikan, yakni harus mampu menghasilkan lulusannya agar dapat bersaing dengan bangsa lain. Akan tetapi, dalam kenyataannya pendidikan yang ada selama ini belum menunjukkan peningkatan yang signifikan, seperti temuan tentang SDM Indonesia yang menduduki level sedang. Human Development Indeks (HDI) pada tahun 2011, menyebutkan bahwa Indonesia menduduki peringkat 124 dari 187 negara Asia dan Afrika, dan peringkat lebih rendah dari lima negara ASEAN(Asia http://hdr.undp.org/en/statistics/)

Sekolah Menengah Kejuruan (SMK) merupakan salah satu penyelenggara pendidikan berbasis kompetensi yang diharapkan mampu memenuhi setiap tuntutan keahlian yang dibutuhkan dunia industri. Oleh karena itu, lulusan SMK diharapkan dapat memenuhi tuntutan dunia usaha dalam hal penyediaan tenaga kerja tingkat menengah. Hal tersebut sesuai dengan PP RI No. 29 Tahun 1990 tentang Pendidikan Menengah pasal 3 ayat 2, yang menyatakan bahwa "Sekolah Menengah Kejuruan mengutamakan penyiapan siswa untuk memasuki lapangan kerja serta mengembangkan sikap profesional". Dalam kenyataannya, sebagian pihak menilai bahwa SMK masih belum mampu dan profesional dalam menyiapkan lulusannya siap pakai di dunia kerja.

Sistem pendidikan di SMK saat ini diharapkan mulai bergeser dari orientasi sekedar mendapatkan ijazah semata, akan tetapi lebih ke orientasi mendapatkan kompetensi untuk menjawab tantangan global. SMK diharapkan proaktif membangun jaringan kerja sama dengan berbagai pihak luar atau industri agar mampu menghasilkan siswa yang teruji kom- petensinya di dunia kerja. Usaha tersebut diharapkan akan mampu memberikan solusi agar tidak lagi terjadi kesenjangan aspek pendidikan antara teori dan praktik di sekolah, dengan praktik lapangan di dunia industri atau dunia kerja yang sesungguhnya. Kerja sama antara pihak sekolah dengan industri dalam bentuk Praktik Kerja Industri (Prakerin).

Secara umum pelaksanaan Prakerin menurut hasil penelitian Sonhadji, dkk. (1997), menghadapi kendala-kendala, antara lain sebagai berikut: (1) pendelegasian tugas dan tanggung jawab di antara perangkat organisasi Pokja Prakerin belum merata, dan ada kecenderungan dominan pada Ketua Pokja, (2) guru pembimbing belum berfungsi secara optimal di industri, dan diantara mereka ada yang tidak relevan dengan bidangnya, (3) kesulitan menjalin kerjasama dengan institusi pasangan yang tergolong menengah dan besar, (4) rendahnya manajemen pengelolaan pelatihan siswa oleh industri, terutama pada industri kecil, (5) instruktur di industri banyak yang tidak memenuhi persyaratan serta belum berperan secara efektif, (6) masih banyak siswa yang mencari sendiri tempat pelatihan industri, (7) kurangnya waktu yang disediakan Majelis Sekolah untuk berkoordinasi, (8) lamanya pengurusan perijinan dan permohonan pelatihan, (9) kurangnya disiplin dan rendahnya kepedulian siswa terhadap keselematan kerja, dan (10) tidak berimbangnya antara jumlah SMK dan jumlah dunia usaha/industri. Dari temuan-temuan di atas dapat simpulkan bahwa pelaksanaan Prakerin selama ini mengalami kendala-kendala struktural, geografis, potensi teknologis, psikologis, akademis, manajerial, dan kultural.

Ada anggapan dan pendapat dari sebagian pihak yang menyatakan, bahwa kinerja lulusan siswa SMK Pariwisata Kompetensi Keahlian Jasa Boga juga dirasakan masih kurang, seperti diungkapkan oleh Lili Hartono (F\&B Manager Hotel Savoy Human Bandung, 2003) yang dikutip Ana, bahwa profil kompetensi yang masih kurang, yaitu pada: (1) Kreativitas dalam proses penggunaan bahanbahan serta penyajian dalam penataan hidangan, (2) performance dan attitude, (3) kemampuan (skill), (4) kecepatan dan ketepatan, (5) Product knowledge tentang bidang pekerjaan di Hotel. Pendapat yang sama dikemukakan oleh Aspandi, seorang kichen chief Hotel Cakra Solo, yang memberikan penilaian bahwa 
siswa SMK dalam menjalankan pekerjaannya masih memperlihatkan sikap lamban dan tampak ragu-ragu.

Suatu penelitian kinerja siswa SMK Pariwisata Kompetensi Keahlian Jasa Boga yang berkaitan dengan program Prakerin dilihat dari sikap siswa kerja di hotel baik di bagian produksi maupun pelayanan diperoleh data 37,50\% masih menunjukkan sikap yang kurang memuaskan (Dwi Kristiastuti; 2004). Selain itu, penelitian Marwanti, dkk (1999), menunjukkan kemampuan profesional lulusan SMK Pariwisata masih menunjukkan perilaku kerja belum memuaskan seperti kecepatan kerja, kecekatan kerja, tanggung jawab, kebersihan dalam penanganan makanan, serta penampilan diri. Dengan demikian dari beberapa fakta penelitian di atas terlihatlah bahwa kinerja yang berkaitan dengan kesiapan kerja lulusan siswa SMK Pariwisata jurusan jasa boga masih kurang mampu bersaing pada dunia kerja baik pada dunia usaha maupun dunia industri. (Ana; Problematika Lulusan SMK Pariwisata di Industri Pariwisata: 2008)

Intensitas guru dalam pembimbingan juga menentukan berhasil dan tidaknya Prakerin siswa, Hal ini diperkuat hasil Penelitian Mirna Arni Mulyani (2011) yang menunjukkan peran guru pembimbing prakerin dalam kategori tinggi serta adanya hubungan yang positif dan signifikan antara peran guru pembimbing dan kesiapan kerja siswa SMK. Ini mengisyaratkan bahwa guru betul-betul diharapkan profesional sebagai komponen penting dalam proses belajar mengajar, sehingga siswa memiliki kesiapan dan kemampuan dalam dunia yang nyata, dan ini sejalan dengan tujuan Prakerin, yaitu menghasilkan tenaga kerja yang memiliki keahlian profesional, serta tenaga kerja yang memiliki tingkat pengetahuan, keterampilan dan etos kerja yang sesuai dengan tuntutan lapangan kerja (Aburizal Bakrie,1996:8 dalam Sugihartono). Dalam pelaksanaannya banyak hal yang tidak sesuai dengan unsur-unsur ideal tersebut, diantaranya, hasil penelitian Sonhadji, dkk. dalam Hario Pamungkas ( 2011: 2), yaitu guru pembimbing belum berfungsi secara optimal di industri, dan di antara mereka ada yang tidak relevan dengan bidangnya, serta instruktur di industri banyak yang tidak memenuhi persyaratan serta belum berperan secara efektif.
Kesiapan kerja yang baik sebagian akan ditunjang oleh bagaimana pelakasanaan Prakerin dari SMK yang merupakan sarana untuk meneguhkan kedudukan sekolah sebagai lembaga pendidikan yang berbasis industri, akan tetapi jika diamati secara cermat dari hasil kelulusannya, Siswa SMK pada umumnya masih belum siap untuk bersaing kerja sesuai kompetensinya. Hal ini terlihat dari beberapa hal berikut: (1) Masih tingginya angka pengangguran terbuka. Berdasarkan data dari BPS untuk pendidikan SMK pada bulan Februari 2012, sebesar 9,51\% menempati peringkat kedua setelah SMA dan jenjang pendidikan lainnya, sehingga jika dicermati untuk pendidikan SMK masih sangat sedikit tingkat keterserapan lulusannya dalam dunia kerja yang menuntut kesiapan dan kemampuan kompetensi yang cukup, (2) Angka keterserapan siswa SMK Pariwisata peningkatannya sangat kecil, hal ini terlihat dari data yang ada pada tahun 2005 dari seluruh pekerja dari sektor pariwisata tenaga kerja lulusan SMK Pariwisata di DIY hanya 10\% yang bekerja di sektor pariwisata, selebihnya lulusan SMU dan Diploma (Kanwil Deparsenibud DIY, 2005 dalam Ana), (3) Hal di atas diperkuat dengan hasil penelitian dari Agnes Warsitaningsih tahun 2002, yang menyatakan bahwa daya serap dari industri pariwisata terhadap lulusan SMK, di hotel dan restoran di DIY, dalam kurun lima tahun terakhir adalah berada pada rentang yang sangat rendah yaitu $0 \%-25 \%$. Dengan demikian permasalahan kesiapan siswa SMK Pariwisata Bidang Keahlian Jasa Boga untuk siap kerja dalam dunia industri maupun membuka lapangan kerja perlu mendapat perhatian yang serius.

Daerah Istimewa Yogyakarta dari tahun ke tahun menunjukkan peningkatan jumlah wisatawan baik mancanegara maupun wisatawan domestik. Pada tahun 2011 wisatawan mancanegara yang berkunjung ke DIY sebesar 169.565 orang, mengalami kenaikan 10\% dari tahun 2010. Tahun 2012 ditargetkan kunjungan wisatawan mancanegara ke DIY sebanyak 200.000 orang, yang akan tercapai pada akhir tahun 2012 (Harian Tribun Jogja, 10 Oktober 2012; hal 3). Oleh karena itu Yogyakarta mendapat predikat sebagai daerah tujuan wisata kedua di Indonesia setelah Bali. Hal di atas dilatarbelakangi oleh banyaknya obyek-obyek pariwisata di Yogyakarta yang masih asli dan bernilai sejarah yang sangat 
tinggi serta unik karena tidak terdapat di daerah lain.

Pemerintah Daerah Istimewa Yogyakarta dalam hal ini Dinas Pariwisata dan badan swasta sebagai mitra kerjanya, telah melakukan pembenahan diri dengan membangun, menata, dan memperluas daerah objek-objek wisata andalan yang ada. Meskipun di Yogyakarta sudah cukup banyak hotel yang relatif memadai, namun perkembangan kepariwisataan di wilayah ini masih akan terus ditingkatkan. Dalam (suaramerdeka.com), disebutkan bahwa hingga bulan Februari 2013 sekurang-kurangnya ada 64 investor baru yang berencana mendirikan hotel di Yogyakarta. Dari jumlah itu 18 investor akan membangun hotel bintang dua hingga bintang lima. Jika hal tersebut benar-benar terwujud, tentu dampaknya selain bisa memperindah kota Yogyakaarta juga bisa menciptakan lapangan kerja baru khususnya di bidang pariwisata (Sugiarto/CN33/JBSM), terutama bagi lulusan SMK Pariwisata Kompetensi Keahlian Jasa Boga.

Apabila ditinjau dari peluang kerja di atas maka sektor pariwisata merupakan penyedia lapangan pekerjaan yang banyak. Adapun penghasilan terbesar pada sektor pariwisata adalah dari usaha makanan dan minuman, bahkan di hotel penghasilan terbesar juga diperoleh dari divisi Food and Beverages Production and Service, sehingga peluang usaha di bidang bisnis makanan dan minuman ini pun sangatlah besar (http://www. indaagro.com). Hal ini harus ditunjang dengan kesiapan kerja yang baik dari lulusan SMK Pariwisata Kompetensi Keahlian Jasa Boga untuk meraih peluang yang ada.

\section{Work Based Learning (WBL)}

Menurut Pardjono (2011: 5), Work Based Learning adalah bentuk pembelajaran kontekstual di mana proses pembelajaran dipusatkan pada tempat kerja dan meliputi program yang terencana dari pelatihan formal dan monitoring, serta pencarian pengalaman kerja yang mendapatkan gaji. Budi Tri Siswanto (2011: 1), menyatakan bahwa Work Based learning atau Pengajaran dan Pembelajaran Berbasis Tempat Kerja (PBTK) adalah pendekatan pembelajaran yang memanfaatkan tempat kerja untuk menstrukturkan pengalaman-pengalaman yang didapat di tempat kerja berkontribusi pada sosial, akademik, dan pengembangan karir pembelajaran dan menjadi suplemen dalam kegiatan pembelajaran. Lebih lanjut dijelaskan bahwa pengalaman belajar di tempat kerja diaplikasikan, diperhalus, diperluas dalam pembelajaran baik di sekolah maupun di tempat kerja. Dengan $W B L$, pembelajaran didesain untuk mengembangkan sikap (attitude), pengetahuan (knowledge), keterampilan (skill), pencerahan (insight), perilaku (behavior), kebiasaan (habits), dan pergaulan (associations) dari pengalaman-pengalaman yang diperoleh di kedua tempat tersebut dan memungkinkan terjadinya pembelajaran yang terkait dengan aktivitas bekerja nyata (real-life work activities). Uraian di atas memberikan gambaran bahwa pelaksanaan Prakerin mempunyai dua tempat kegiatan pembelajaran, yakni pembelajaran yang berbasis sekolah (school based learning) dan berbasis kerja (work based learning). WBL juga digunakan sebagai acuan di berbagai negara untuk program-program pada sekolah atau perguruan tinggi guna memperoleh pengalaman dari dunia kerja. Bagi para remaja yang berada di masa transisi, yakni dari sekolah ke dunia kerja nyata, juga akan menjadi lebih siap untuk merencanakan pilihan pekerjaan atau karier yang sesuai dengan kompetensi keahlian masing-masing. Raelin (2008: 2), menyatakan bahwa WBL merupakan pembelajaran aksi (action learning) yang tidak dapat dilepaskan dari konteks pembelajaran organisasi (organizational learning) maupun organisasi belajar (learning organization). Sehingga dalam pelaksanaannya dapat saling melengkapi dan dapat saling kerja sama antara organisasi/ DUDI dengan pihak dunia pendidikan/sekolah.

\section{Praktik Kerja Industri (Prakerin)}

Dalam pedoman Praktik Kerja Industri (Prakerin) SMK Tahun Pelajaran 2012/2013, (2012: 2) dijelaskan bahwa:

Praktik Kerja Industri adalah suatu bentuk penyelenggaraan pendidikan keahlian profesional yang memadukan secara sistematis dan sinkron antara program pendidikan di sekolah dengan program penguasaan keahlian melalui kegiatan bekerja langsung di dunia kerja yang terarah untuk mencapai suatu tingkat keahlian profesional tertentu.

Pengertian Prakerin di Amerika (Fink, 2007:3) yaitu "to obtain experience from work and for young people to be prepared for the 
transition from school to work and, to learn the realisties of work and be prepared to make the right choice of work", yakni suatu pengalaman kerja bagi siswa yang disiapkan untuk masa peralihan dari sekolah ke lingkungan kerja, memahami dunia kerja nyata dan persiapan untuk memilih pekerjaan yang sesuai. Fink (2007:4) memberikan pengertian bahwa Prakerin adalah "an approach which focuses upon the practical utility of learning and is there fore direcly relevant to learners and their work environment", yaitu suatu pendekatan pembelajaran praktik kerja industri yang bisa dilakukan di berbagai tempat dengan situasi dan kondisi yang berbeda yang sesuai dengan topik pembelajaran dan lingkungan tempat kerja.

Reeve and Gallacher (University Vocational Awards Council, 2005: 13) berpendapat ada empat konsep yang menjadi bagian penting dari pelaksanaan prakerin yaitu: (1) Partnership/kemitraan,(2) Flexibility/ keluwesan, (3) Relevance/ kesesuaian, dan (4) Accreditation/terakreditasi. Menurut Wardiman ( 1998: 80), program Prakerin bertujuan untuk; (1) menghasilkan tenaga kerja yang berkualitas, (2) memperkokoh link and match antara SMK dengan dunia kerja, (3) meningkatkan efektivitas dan efisiensi proses pendidikan dan pelatihan tenaga kerja berkualitas, (4) memberikan pengakuan dan penghargaan terhadap pengalaman kerja sebagai bagian dari proses pendidikan. Dari tujuan tersebut jelaslah bahwa siswa lulusan SMK seharusnya lebih siap dan lebih mampu menembus dunia kerja serta lebih bisa bersaing dalam bidang pekerjaan sesuai kompetensinya.

Wardiman (1998:80) juga menyatakan bahwa pelaksanaan Prakerin akan berjalan dengan baik apabila terdapat komponen-komponen sebagai berikut: (1) institusi pasangan, (2) program pendidikan dan pelatihan bersama, (3) sistem penilaian dan sertifikasi, (4) kelembagaan kerja sama, (5) nilai tambah dan insentif, serta (6) jaminan keterlaksanaan. Dengan demikian, sebelum siswa berangkat Prakerin harus sudah memiliki kesiapan dalam beberapa hal penting yaitu pengetahuan dasar, wawasan, dan keterampilan.

\section{Motivasi Belajar}

Menurut M. Sobary Sutikno (2012:88), motivasi berpangkal dari kata motif yang dapat diartikan sebagai daya penggerak yang ada di dalam diri seseorang untuk melakukan aktivitas-aktivitas tertentu demi tercapainya suatu tujuan. Bahkan motif dapat diartikan sebagai suatu kondisi intern (kesiapsiagaan). Menurut pendapat Sardiman (2011: 73), "Motivasi berasal dari kata motif yang berarti daya upaya yang mendorong seseorang untuk melakukan sesuatu". Pengertian motivasi menurut Depdikbud (1998: 66) "Motivasi adalah dorongan yang timbul pada diri seseorang secara sadar atau tidak sadar untuk melaksanakan suatu tindakan dengan tujuan tertentu". Sedangkan menurut Nana Syaodih Sukmadinata (2007: 381), "Motivasi adalah suatu kondisi dalam diri individu atau peserta didik yang mendorong atau menggerakkan individu atau peserta didik melakukan kegiatan mencapai suatu tujuan".

Menurut Nana Syaodih Sukmadinata (2004: 62) "Motivasi memiliki dua fungsi, yaitu: (a) mengarahkan (directional function), (b) mengaktifkan dan meningkatkan kegiatan (activating and energizing function)".Menurut Sardiman (2004: 54), motivasi yang ada pada diri setiap orang memiliki ciri-ciri atau karakteristik sebagai berikut: (1) tekun menghadapi tugas (dapat bekerja terus-menerus dalam waktu yang lama, tidak pernah berhenti sebelum selesai), (2) ulet menghadapi kesulitan (ulet dalam memecahkan berbagai masalah dan hambatan, tidak mudah putus asa), (3) tidak memerlukan dorongan dari luar untuk berprestasi sebaik mungkin (tidak cepat puas dengan prestasi yang telah dicapainya), (4) menunjukkan minat terhadap bermacam-macam masalah "untuk orang dewasa" (peka dan responsif terhadap berbagai masalah umum, misalnya masalah pembangunan, agama, politik, ekonomi, keadilan, pemberantasan korupsi, penentangan terhadap setiap tindak kriminal, amoral, dan sebagainya), (5) lebih senang bekerja mandiri, (6) cepat bosan pada tugastugas yang rutin (hal-hal yang bersifat mekanis, berulang-ulang begitu saja, sehingga kurang kreatif), (7) dapat mempertahankan pendapat (kalau sudah yakin akan sesuatu dan dipandangnya cukup rasional), (8) tidak mudah melepaskan hal yang diyakini itu, dan (9) senang mencari dan memecahkan masalah.

Beberapa faktor yang mempegaruhi motivasi belajar yaitu: (1) faktor individual, yaitu suatu faktor dari dalam seorang individu itu sendiri, seperti; kematangan atau pertumbuhan, kecerdasan, latihan, motivasi, dan fak- 
tor pribadi, (2) faktor sosial, yaitu suatu faktor yang berasal dari kehidupan sekitar atau masyarakat, seperti; keluaga atau keadaan rumah tangga, guru dan cara mengajarnya, alat-alat dalam belajar, dan motivasi sosial (Purwanto, 2002:102).

\section{Kinerja Prakerin Siswa}

Beberapa pendapat pengertian penilaian kinerja yang dirangkum dalam (web.id Media Pendidikan Indonesia), yaitu Menurut Bernardin dan Russel ( 1993: 379) “ A way of measuring the contribution of individuals to their organization ". Penilaian kinerja adalah cara mengukur terhadap seberapa besar kontribusi individu (karyawan) kepada organisasi tempat ia bekerja. Menurut Cascio (1992 : 267), "Penilaian kinerja adalah sebuah gambaran atau deskripsi yang sistematis tentang kekuatan dan kelemahan yang terkait dengan seseorang atau suatu kelompok". Menurut John Whitmore (1997 : 104), "Kinerja adalah pelaksanaan fungsi-fungsi yang dituntut dari seseorang, yang berupa suatu perbuatan, suatu prestasi, suatu pameran umum keterampilan". Menurut Barry Cushway (2002 : 198) "Kinerja adalah menilai tentang bagaimana seseorang telah bekerja yang dikaitkan dengan target yang telah ditentukan". Dan menurut Veizal Rivai (2004: 309) mengemukakan, bahwa kinerja merupakan perilaku yang nyata yang ditampilkan oleh setiap orang sebagai prestasi kerja yang dihasilkan sesuai dengan perannya dalam perusahaan.

Menurut Robert L. Mathis dan John H. Jackson (2001: 82) faktor-faktor yang mempengaruhi kinerja individu sebagai tenaga kerja, yaitu: (1) kemampuan mereka, (2) motivasi, (3) dukungan yang diterima, (4) keberadaan pekerjaan yang mereka lakukan, dan (5) hubungan mereka dengan organisasi. (www.m-edukasi.web.id Media Pendidikan Indonesia).

Penilaian kinerja (performance) mempunyai komponen-komponen yang akan merupakan hal-hal yang perlu disiapkan oleh penilai. Menurut Dantes dalam Endang Sadbudi dan Made Nuryata (2010:124), terdapat tiga komponen utama dalam penilaian (asesmen) kinerja, yaitu: tugas kinerja (performance task), rubrik performansi (performansi rubrics), dan cara penilaian (scoring guide). Selain itu juga dijelaskan tentang lingkup dari masing-masing komponen penilaian kinerja tersebut, yaitu bahwa tugas kinerja adalah suatu tugas yang berisi topik, standar tugas, deskripsi tugas, dan kondisi penyelesaian tugas. Rubrik performansi merupakan suatu rubrik yang berisi komponen-komponen suatu performansi ideal, dan deskripsi dari setiap komponen tersebut.

Berdasarkan beberapa pendapat tersebut, maka dalam penelitian ini indikator yang digunakan untuk mengukur kinerja siswa jasa boga selama menempuh Prakerin yang dapat dikelompokkan menjadi: (1) kualitas pekerjaan, (2) kuantitas pekerjaan, dan (3) ketepatan waktu. Ketiga hal tersebut akan tersirat dalam tugas yang akan menjadi tanggung jawab setiap siswa SMK Pariwisata Kompetensi Keahlian Jasa Boga. Adapun daftar tugas atau jenis pekerjaan yang harus dilaksanakan siswa jasa boga tersebut terdiri dua bagian, yaitu food and beverages service dan food and beverages product.

Adapun penilaian kinerja Prakerin siswa SMK Pariwisata Kompetensi Keahlian Jasa Boga meliputi dua aspek yaitu :

\section{Food and Beverages Product}

Tabel 1. Daftar aspek penilaian Prakerin food and beverages product

ASPEK TEKNIS

\begin{tabular}{cl}
\hline No. & KEMAMPUAN YANG DINILAI \\
\hline \multirow{2}{*}{1} & Persiapan kerja \\
& - Menyiapkan ruangan/area restoran \\
& - Menyiapkan dan mengatur meja \\
& Proses Kerja \\
2 & - Mengambil dan memproses makanan \\
& - Menyajikan dan membersihkan rak \\
& dan minuman \\
3 & Menutup Area Restoran \\
\hline
\end{tabular}

ASPEK NONTEKNIS

\begin{tabular}{cl}
\hline No. & ASPEK YANG DINILAI \\
\hline 1 & Disiplin \\
2 & Kerjasama \\
3 & Inisiatif \\
4 & Tanggung Jawab \\
5 & Kebersihan \\
\hline
\end{tabular}


Food and Beverages Service

Tabel 2. Daftar aspek penilaian Prakerin food and beverages product

ASPEK TEKNIS

\begin{tabular}{cl}
\hline No. & Kemampuan yang Dinilai \\
\hline 1 & Persiapan kerja \\
& - Bahan dan Alat \\
& - Pakaian Kerja \\
2 & Proses Kerja \\
& - Sistematika Kerja \\
& - Menyalakan \\
& - Menghias \\
& - Menata \\
3 & Hasil Kerja \\
& - Bentuk \\
& - Warna \\
& - Rasa \\
& - Tekstur \\
\hline ASPEK NONTEKNIS \\
\hline No. & Aspek yang Dinilai \\
\hline 1 & Disiplin \\
2 & Kerjasama \\
3 & Inisiatif \\
4 & Tanggung Jawab \\
5 & Kebersihan \\
\hline
\end{tabular}

Intensitas Pembimbingan Guru Prakerin

Menurut Chaplin (2000: 108), intensitas adalah kedalaman atau reaksi emosional dan kekuatan yang mendukung suatu pendapat atau sikap keluarga lainnya. Menurut Gunarsa (2004), intensitas komunikasi dapat diukur dari apa-apa dan siapa yang dibicarakan, pikiran, perasaan, objek tertentu, orang lain atau dirinya sendiri. Ditambahkannya lagi, bahwa intensitas komunikasi yang mendalam ditandai oleh kejujuran, keterbukaan, dan saling percaya, sehingga menimbulkan respon dalam bentuk perilaku atau tindakan.

Pembimbing dalam Prakerin, terdiri dari pembimbing dari sekolah dan dari industri. Adapun tugas dan peranan dari pembimbing dari sekolah di antaranya: (1) mengantar dan menyerahkan peserta Prakerin kepada pimpinan DU/DI atau instruktur DU/DI tempat siswa akan melaksanakan praktik, (2) menyerahkan daftar hadir kepada instruktur DU/DI, (3) melaksanakan monitoring dan evaluasi sesuai jadwal, (4) mencatat segala kejadian penting selama pelaksanaan monitoring dan evaluasi, (5) membimbing siswa Prakerin dalam mengisi agenda dan jurnal, serta membuat laporan hasil Prakerin, (6) menandatangani daftar hadir dan jurnal hasil kerja siswa, (7) menyerahkan hasil monitoring dan evaluasi siswa kepada panitia Prakerin, (8) memberikan informasi (sosialisasi) tentang sanksi kepada siswa yang melanggar peraturan atau tata tertib dengan ketentuan, yaitu sanksi ringan oleh pembimbing (peringatan berupa teguran), sanksi sedang oleh pembimbing (pemanggilan siswa dan orang tua ke sekolah serta memindahkannya ke tempat lain yang memungkinkan), sanksi berat oleh pembimbing dan humas (pemanggilan orang tua dan siswa dan menarik siswa dari tempat kerja dan menunda pelaksanaan Prakerin), (9) memantau perkembangan siswa di luar jadwal bimbingan (selama pelaksanaan Prakerin) terutama bagi siswa yang telah diberi sanksi, (10) meningkatkan hubungan kerja sama secara dinamis berupa masukan-masukan yang terkait dengan pengembangan kurikulum dan penyerapan tamatan, (11) memberikan masukan penting tentang hasil pelaksanaan Prakerin (relevansi program studi keahlian siswa dengan DU/DI tempat siswa praktik, alternatif DU/DI lain yang relevan untuk kompetensi keahlian siswa), (12) memberitahukan dan menjelaskan pembimbing DU/DI mengenai penilaian aspek teknis dan non-teknis, (13) mengambil sertifikat dari DU/DI, dan (14) menyerahkan laporan hasil Prakerin siswa kepada panitia.

Pembimbing di DU/DI juga mempunyai peranan dan tugas yang tidak kalah pentingnya untuk keberhasilan pelaksanaan Prakerin. Adapun tugas dan peranannya itu di antaranya: (1) menjelaskan dan membimbing kepada peserta Prakerin tentang latar belakang dunia industri/dunia usaha, tata tertib DU/DI, environment health dan safety yang berlaku, main job dan additional job yang ada di DU/ DI, keterampilan yang sesuai dan bisa dilakukan oleh DU/DI, ( 2) monitoring kehadiran \& kegiatan peserta diklat, (3) mengesahkan buku jurnal peserta didik, dan (4) menilai peserta didik yang terdiri dari : aspek teknis dan aspek non-teknis (Akhmad Sudrajad. 2011: 7)

Menurut Dikmenjur (1997), guru dipandang sebagai ujung tombak yang sangat menentukan keberhasilan dalam pelaksanaan Prakerin. Secara khusus, guru dalam Prakerin didefinisikan sebagai berikut : "Guru Prakerin adalah individu yang memiliki kemampuan kompetensi, profesi keguruan atau pendidik 
secara dominan, tetapi juga harus memiliki kompetensi teknis keahlian tertentu dan memiliki jiwa entrepreneurship. Dalam pelaksanaan Prakerin guru dipersyaratkan harus memiliki sejumlah kompetensi atau kemampuan dasar yang dibutuhkan untuk melaksanakan keprofesiannya dalam melaksanakan tugas dan tanggung jawabnya sebagai guru Prakerin.

\section{Persepsi}

Gary Johns (1988), mengatakan bahwa persepsi merupakan the process of interpreting the messages of our senses to provide order end meaning to the environment. Pendapat ini lebih menekankan pada perasaan seseorang dalam proses menginterpretasikan pesan-pesan yang muncul. Lebih jauh Gary Johns mengatakan "The world is a complex place, and perceptions help us sort out and organize the input received by our sense of sight, smell, touch, taste, and hearing". Pernyataan ini menggambarkan bahwa persepsi sangat membantu seseorang dalam memilahmilah dan menggabungkan berbagai pesan yang diterima.

Pada dasarnya, terdapat dua faktor yang secara umum dapat mempengaruhi terhadap persepsi seseorang, yaitu faktor internal (faktor yang berasal dari dalam individu) dan faktor eksternal (faktor yang berasal dari luar individu). Adapun faktor internal antara lain: (1) fisiologi, (2) perhatian, (3) minat, (4) kebutuhan yang searah, (5) pengalaman dan ingatan. (6) suasana hati. Faktor-faktor eksternal yang dapat mempengaruhi persepsi adalah: (1) ukuran dan penempatan dari obyek atau stimulus. (2) warna dari obyek-obyek. Obyek-obyek yang mempunyai cahaya lebih banyak, akan lebih mudah dipahami (to be perceived) dibandingkan dengan yang sedikit cahaya, (3) keunikan dan kekontrasan stimulus. (4) intensitas dan kekuatan dari stimulus. Stimulus dari luar akan memberi makna yang lebih apabila lebih sering diperhatikan, jika dibandingkan dengan yang hanya sekali dilihat. Kekuatan dari stimulus merupakan daya dari suatu objek yang bisa mempengaruhi persepsi.

\section{Kesiapan Kerja}

Sugihartono (1991: 15) yang dimaksud dengan kesiapan kerja adalah: Kondisi yang menunjukkan adanya keserasian antara kematangan fisik, mental serta pengalaman be- kerja, sehingga individu mempunyai kemampuan untuk melaksanakan suatu kegiatan tertentu dalam hubungan dengan pekerjaan. Menurut Herminanto Sofyan (1992: 20) mengenai kesiapan kerja, yaitu: Kurikulum SMK memberikan mata pelajaran praktik kejuruan. Jadi untuk mendukung kesiapan kerja pada diri siswa selain terbentuknya kematangan fisik dan kematangan mental ditambah juga dengan pengalaman belajar dan pengalaman praktik luar.

Menurut Laela Nur Farida (2010: 45) dalam penelitiannya, menyebutkan bahwa faktor-faktor lain yang mempengaruhi kesiapan siswa dalam menghadapi dunia kerja meliputi:1) faktor pribadi siswa yang meliputi intelegensi, sifat-sifat, strategi mengajar, dan minat; 2) faktor On The Job Training, yang mencakup dunia industri (instruktur/pembimbing dari industri) dan sekolah (guru pembimbing OJT yang relevan), kegiatan belajar di industri, dan bakat khusus. Hal diatas didukung oleh teori prosser yang menyebutkan Prakerin akan berhasil (efektif) dengan baik salah satunya jika guru pendampingnya mempunyai pengalaman yang baik dalam penerapan kompetensi pada operasi dan proses kerja yang telah dilakukan; 3) faktor kurikulum yang meliputi kurikulum, kelembagaan dan tempat belajar.

\section{METODE}

\section{Jenis atau Desain Penelitian}

Penelitian ini merupakan penelitian "expost facto" yaitu suatu penelitian yang berusaha mengungkap fakta berdasar pengukuran gejala yang telah ada pada diri responden dalam arti pengambilan data dilakukan setelah terjadi masalah. Selain itu expost facto digunakan karena penelitian ini mengungkap peristiwa yang terjadi dan kemudian merunut kebelakang untuk mengetahui faktor-faktor yang dapat menimbulkan kejadian tersebut tanpa memberikan perlakuan atau manipulasi variabel yang diteliti. Tujuan Penelitian yaitu menemukan pengaruh antara variabel bebas dan variabel terikat. Variabel bebas dalam penelitian ini terdiri dari tiga variabel yaitu Motivasi belajar, Kinerja prakerin, Intensitas pembimbingan guru prakerin dan satu variabel terikat adalah Kesiapan kerja.

\section{Tempat dan Waktu Penelitian}

Tempat penelitian adalah Sekolah Menengah Kejuruan Pariwisata se-Daerah Isti- 
mewa Yogyakarta yang memiliki kompetensi keahlian jasa boga. Data yang diperoleh, SMK se-Daerah Istimewa Yogyakarta terdiri 11 SMK baik negeri dan swasta yang tersebar di empat kabupaten dari lima kabupaten yang ada di DIY, yaitu Kabupaten Sleman, Kota Yogyakarta, Kabupaten Bantul dan kabupaten Gunung Kidul. peneltiannya dilaksanakan pada bulan Maret sampai April 2013.

\section{Populasi dan Sampel Penelitian}

Populasi dalam penelitian ini adalah Siswa SMK Pariwisata kelas XII tahun 20122013 kompetensi keahlian jasa boga yang sudah melaksanakan praktek kerja industri yang tercatat sebagai siswa di SMK Pariwisata yang berada di daerah Istimewa Yogyakarta. Dari data yang diperoleh dari Prasurvai diperoleh data siswa sebanyak 629 siswa dari 11 SMK, sehingga populasi dari penelitian ini adalah 629 siswa.

Penentuan sampel dalam penelitian ini adalah dengan teknik Proportional cluster random sampling serta dalam penetapan banyaknya sampel, menggunakan nomogram Hary King (Sugiyono,2011:129). Penentuan jumlahlsiswa tiap sekolah dengan ukuran anggota sampel (sample number), maka diperoleh sampel 262 siswa.

\section{Variabel Penelitian}

Adapun yang merupakan variabel independen dalam penelitian ini terdiri dari tiga variabel yaitu motivasi belajar, kinerja prakerin, dan intensitas pembimbingan guru prakerin serta satu variabel terikatnya adalah kesiapan kerja siswa.

\section{HASIL PENELITIAN DAN PEMBAHASAN}

Hasil uji hipotesis memperlihatkan bahwa seluruh variabel bebas yaitu motivasi belajar, kinerja Prakerin, Intensitas pembimbingan guru Prakerin terhadap kesiapan kerja. Hasil tersebut menunjukan bahwa dalam meningkatkan Kesiapan kerja dipengaruhi beberapa faktor yaitu motivasi belajar, kinerja Prakerin dan intensitas pembimbingan guru Prakerin. Selain itu secara Deskriptif hasil penelitian disajikan pada Tabel 3.

Berdasarkan Tabel 3 dapat diketahui kecenderungan motivasi belajar siswa saat prakerin memiliki kategori sangat tinggi sebesar 6,49\%, kategori tinggi sebesar 24,04\%. Kategori sedang sebesar $35,88 \%$. Kategori rendah sebesar 24,04\% Kategori sangat rendah sebesar 09,54\%. Kecenderungan kinerja Prakerin pada kategori sangat tinggi sebesar $01,15 \%$. Kategori tinggi sebesar $09,54 \%$. Kategori sedang sebesar 30,92\%. Kategori rendah sebesar $37,02 \%$. Kategori sangat rendah sebesar $17,56 \%$ dari seluruh responden. Kecenderungan intensitas pembimbingan guru Prakerin yaitu kategori sangat tinggi sebesar $09,16 \%$. Kategori tinggi sebesar 25,57\%. Kategori sedang sebesar 30,53\%. Kategori rendah sebesar $25,19 \%$. Kategori sangat sebesar 09,54\%. Kecenderungan Kesiapan kerja yaitu kategori sangat tinggi sebesar 00,38\%. Kategori tinggi sebesar $17,56 \%$. Kategori sedang sebesar $37,41 \%$. Kategori rendah sebesar $33,21 \%$. Kategori sangat rendah sebesar $11,45 \%$.

Tabel 3. Rangkuman Kategori Kecenderunga Variabel dalam Persen

\begin{tabular}{lcccc}
\hline & X1 & X2 & X3 & Y \\
\hline Sangat Tinggi & 17 & 3 & 24 & 1 \\
Tinggi & 63 & 25 & 67 & 46 \\
Sedang & 94 & 81 & 80 & 98 \\
Rendah & 63 & 97 & 66 & 87 \\
Sangat Rendah & 25 & 46 & 25 & 30 \\
\hline
\end{tabular}

Hasil dari uji hipotesis pengaruh antara motivasi belajar (X1) terhadap kesiapan kerja (Y) diperoleh hasil, dengan menggunakan regresi sederhana didapatkan nilai koefisien korelasi positif sebesar 0,207 , nilai signifi-kansi sebesar 0,000 $(\mathrm{p}<0,05)$ dan harga $R$ Square $\left(R^{2}\right)$ sebesar 0,10 . Artinya terdapat pengaruh yang positif signifikan antara motivasi belajar (X1) terhadap kesiapan kerja (Y) siswa SMK Pariwisata kompetensi keahlian Jasa Boga di DIY. Pengaruh kinerja Prakerin (X2) terhadap kesiapan kerja (Y) diperoleh hasil, dengan menggunakan regresi sederhana didapatkan nilai koefisien korelasi positif sebesar.0,080, nilai signifikansi sebesar $0,000(\mathrm{p}<0,05)$ dan harga $R$ Square $\left(R^{2}\right)$ sebesar 0,020 . Artinya terdapat pengaruh yang positif dan signifikan antara kinerja Prakerin terhadap kesiapan kerja siswa SMK kompetensi keahlian Jasa Boga di DIY. Pengaruh intensitas pembimbingan guru Prakerin (X3) terhadap kesiapan kerja (Y) diperoleh hasil, dengan menggunakan regresi sederhana didapat nilai koeisien korelasi positif sebesar 0,527 , nilai signifikansi sebesar 0,000 $(\mathrm{p}<0,05)$ dan harga $R$ 
Square $\left(R^{2}\right)$ sebesar 0,247 . Artinya terdapat pengaruh yang positif dan signifikan antara Intensitas pembimbingan guru Prakerin terhadap kesiapan kerja. Pengaruh secara bersama antara motivasi belajar (X1), kinerja Prakerin (X2), intensitas pembimbingan guru Prakerin (X3) terhadap kesiapan kerja (Y) diperoleh hasil dengan menggunakan regresi ganda didapat nilai koeisien korelasi variabel motivasi belajar (X1) sebesar 0,258, variabel kinerja Prakerin (X2) sebesar 0,270, variabel intensitas pembimbingan guru Prakerin (X3) sebesar 0,592. nilai signifikansi sebesar 0,000 $(p<0,05)$ dan harga $R$ Square $\left(R^{2}\right)$ sebesar 0,403 , dengan demikian dapat disimpulkan bahwa motivasi belajar (X1), kinerja prakerin (X2), intensitas pembimbingan guru prakerin (X3) secara bersama-sama memberikan pengaruh sebesar 40,3\% terhadap kesiapan kerja (Y) siswa SMK Pariwisata Kompetensi Keahlian Jasa Boga di DIY, sehingga 59,7\% dimungkinkan dipengaruhi oleh variabel-variabel lain yang tidak diteliti dalam penelitian ini. Selain itu dapat dilihat hasil dari nilai $\mathrm{F}$ hitung lebih besar dari $\mathrm{F}$ tabel dengan $\mathrm{dk}$ atau $\mathrm{df}=(\mathrm{n}-\mathrm{k}-1)$ yaitu $(262-3-1=259)$ adalah 2,639. Hal ini menunjukkan $\mathrm{F}$ hitung $>\mathrm{F}$ tabel yaitu 59,790 > 2,639. Dengan demikian maka hipotesis keempat terbukti, yaitu ada pengaruh positif dan signifikan antara motivasi belajar (X1), kinerja Prakerin(X2), intensitas pembimbingan guru Prakerin (X3) terhadap Kesiapan kerja (Y) siswa SMK Pariwisata kompetensi keahlian Jasa Boga di DIY.

\section{SIMPULAN}

Secara deskriptif masing-masing variabel dalam penelitian ini dapat disimpulkan sebagai berikut, Motivasi belajar siswa SMK Pariwisata kompetensi keahlian jasa boga di DIY diperoleh kategori sedang sebesar $35,88 \%$. Kinerja prakerin siswa SMK Pariwisata kompetensi keahlian jasa boga di DIY diperoleh kategori rendah sebesar 37,02\%. Intensitas pembimbingan guru prakerin kompetensi keahlian jasa boga di DIY diperoleh kategori sedang sebesar 30,53 \%. Kesiapan kerja siswa SMK Pariwisata kompetensi keahlian jasa boga di DIY diperoleh kategori sedang sebesar $37,41 \%$

Berdasarkan hasil uji hipotesis maka dapat disimpulkan, motivasi belajar berpengaruh positif dan signifikan terhadap kesiapan kerja siswa SMK Pariwisata Kompe- tensi Keahlian Jasa Boga di DIY. Kinerja Prakerin berpengaruh positif dan signifikan terhadap kesiapan kerja siswa SMK Pariwisata Kompetensi Keahlian Jasa Boga di DIY. Intensistas pembimbingan guru Prakerin berpengaruh positif dan signifikan terhadap kesiapan kerja siswa SMK Pariwisata Kompetensi Keahlian Jasa Boga di DIY. Motivasi belajar, kinerja prakerin, intensitas pembimbingan guru prakerin secara bersama-sama berpengaruh positif dan signifikan terhadap kesiapan kerja siswa SMK pariwisata kompetensi keahlian jasa boga di DIY.

\section{Saran}

Motivasi belajar siswa selama Prakerin dapat ditumbuhkan selain dari diri sendiri siswa akan tetapi juga tidak kalah pentingnya diberikan dari beberapa pihak, diantaranaya dari orang tua (keluarga), sekolah, maupun industri. Program sekolah yang baik maka akan memberikan layanan dan fasilitas yang baik pula pada siswa yang akan Prakerin. Menyiapkan guru pembimbing yang sesuai kompetensi keahliannya sehingga siswa yang dibimbing menjadi lebih termotivasi. Selain itu juga dari pihak industri juga diharapkan menerima siswa yang Prakerin benar-benar memberikan kontribusi penambahan pengetahuan sesuai kompetensi keahlian.

Kinerja Prakerin merupakan pengalaman kerja yang nyata, hal ini dikarenakan siswa benar-benar melakukan aktifitas dalam industri sesuai kompetensi keahliannya dan sesuai job deskripsinya dalam bidang pelayanan jasa boga baik dalam bidang food and beverages produc maupun food and bevages service sehingga diharapkan menjadikan pengalaman pembelajaran yang nantinya akan menjadikan salah satu faktor pendukung siswa memasuki dunia kerja dan dunia industri. Dengan demikian perlu kiranya sinkronisasi ulang tentang kompetensi-kompetensi yang diajarkan disekolah maupun diindustri.

Intensitas Pembimbingan Guru Prakerin merupakan bagaimana guru pembimbing Prakerin dari sekolah maupun guru pembimbing dari industri memberikan pendampingan kepada siswa. Selama ini guru pembimbing dari sekolah belum banyak memperhatikan latar belakang pendidikannya. Untuk itu agar lebih baiknya dari suatu pembimbingan selama Prakerin adalah sebaiknya dipilihkan dari guru yang sesuai dengan kompetensi keahlian 
siswa yang Prakerin sehingga jika siswa mengalami hal-hal yang berkenaan suatu pekerjaan dapat memberikan solusi dan bimbingan sesuai yang diharapkan siswa.

Kesiapan kerja merupakan suatu hal yang harus dimiliki siswa SMK baik yang ingin lanjut atau yang tidak lagi ingin melanjutkan kejenjang pendidikan yang lebih tinggi. Dengan demikian diharapkan siswa selama menempuh pendidikan baik disekolah maupun di DUDI benar-benar menjadi tanggung jawab semua pihak, sehingga siswa akan benar-benar siap untuk bekerja.

\section{DAFTAR PUSTAKA}

Ana. (2008). Problematika Lulusan SMK Pariwisata di Industri Pariwisata Jasa Boga. tidak diterbitkan. http://file.upi. edu/Direktori/FPTK/JUR._PEND._KE SEJAHTERAAN_KELUARGA/19720 3071999032ANA/Presentasi_problemat ika_smk_boga.pdf

Badan Pusat Statistik. (2012). Berita resmi statistik.Yogyakarta: BPS Provinsi DIY

Chaplin, J.P. (2002). Kamus lengkap psikologi. Penerjemah: Kartini Kartono. Jakarta: PT. Raja Grafindo.

DikmenjurKanwilDiknas Yogyakarta http://www.indagagrojabar.comTerusbe rupayamempertahankanwarisankulinerb angsa.Didownloadtg14februari2008.

Ditpsmk. (2011). Data Pokok SMK Versi 2.0 Beta. Diambil pada tanggal 19 Agustus 2012, dari http://datapokok.ditpsmk.net/ index.php? nama $=\&$ prop $=04 \& \mathrm{kab}=040$ 2\&smk.

Sadbudy, E., \& Nuryata, I.M. (2010). Pembelajaran Masa kini. Jakarta: Se-karmita training and publishing.

Farida, L.N. (2010). Analisis Faktor-Faktor yang Mempengaruhi Kesiapan Kerja Siswa Kelas XI Program Keahlian Administrasi Perkantoran SMK Negeri I Boyolali, Skripsi. FE Universitas Negeri Semarang

Fink, K. F., Rokkjaer, O., \& Schrey, K. (2007). Work based learning and facilitated work based learning. Aalborg : TREE (Teaching and Research in Engineering in Europe).

Gary, Johns. (1988). Organizational behavior; understanding life at Work. Dallas: Scott.
Hartono, L. (2003).Makalah Semnas: Implementasi Kurikulum SMK 2004 dan Harapan Dunia Industri. UPI.

Mulyani, M.A. (2011). Peran Guru Pembimbing dalam Kesiapan Kerja Siswa SMK Negeri 2 Sawahlunto Sumatera Barat.Tesis. tidak diterbitkan.

Pardjono. (2011). Peran Industri Dalam Pengembanga SMK, FT.UNY. http:// static.flipora.com/enhancedsearch v.ht $\mathrm{ml} ? \mathrm{q}=$ pengertian+work-based+learning $\& c x=$ partner-pub-6808396145675874 \%3A8328618497\&cof=FORID\%3A10

Reeve \& Gallacher. (2005). Integrating WorkBased Learning into Higher Education: A Guide to Good Practice.Diambil pada tanggal 20 oktober 2012, dari http:// www.uvac.ac.uk/downloads/0401_publ ications/int wbl .pdf.

Siswanto, B.T. (2011). Pendidikan vokasi, work-based learning, dan penyelenggaraan program: UNY, tidak diterbitkan.

Sugiyono. (2011). Metode penelitian Pendidikan Pendekatan Kuantitatif, kualitatif, dan $R \& D$. Bandung: Alfabeta.

Sugihartono, (1991), "Aspirasi Siswa terhadap Pekerjaan dan Prestasi Akademik kaitannya dengan Kesiapan memasuki Kerja pada Siswa Sekolah Kejuruan di DIY', Laporan Penelitian, FIP IKIP Yogyakarta.

Sukmadinata, N. S. (2004). Landasan Psikologis Proses Pendidikan. Jakarta: Remaja Rosdakarya.

Sukmadinata, N.S., Ayi, N.J., Ahman. (2007). Pengendalian Mutu Pendidikan Sekolah Menengah (konsep, prinsip, dan Instrumen). Bandung : PT. Refika Aditama.

Tribun Jogja (2012) Kunjungan Wisata DIY . (November 2nd 2011). International human development indicators. editorially independent publication commissioned by the United Nations Development Programme, Asia http://hdr.undp. org/en/statistics/)

. (8 september 2012). Terus berupaya mempertahankan warisan kuliner bangsa, didownload tanggal 17 April 2013. dari http://www.indaagro.com

Wardiman, Djojonegoro. (1998). Pengembangan Sumberdaya manusia melalui Sekolah Menengah Kejuruan (SMK). Jakarta: PT Jayakarta Agung Offset. 